\title{
Pengaruh Disiplin Kerja Terhadap Kinerja Pegawai pada Biro Pemerintahan Setda Provinsi Jambi
}

\author{
Sudirman, Ubaidillah \\ Fakultas Ekonomi Universitas Batanghari Jambi \\ sudirman@unbari.ac.id, ubaidillah@unbari.ac.id
}

\begin{abstract}
Human resource management is one of the fields of general management which includes aspects of planning, organizing, implementing, and controlling. This process is found in the fields of production, marketing, finance, or staffing. Because human resources are considered to be increasingly important role in achieving company goals, various experiences and results of research in the HR field are systematically collected in what is called human resource management. The term "management has the meaning of knowledge about how to manage human resources.
\end{abstract}

Keyword:

The discipline of work, performance, governance

\section{PENDAHULUAN}

Manajemen sumber daya manusia merupakan salah satu bidang dari manajemen umum yang meliputi segi-segi perencanaan, pengorganisasian, pelaksanaan, dan pengendalian. Proses ini terdapat dalam bidang /fungsi produksi, pemasaran, keuangan, ataupun kepegawaian. Karena sumber daya manusia diangggap semakin penting perannya dalam pencapaian tujuan perusahaan, maka berbagai pengalaman dan hasil penelitian dalam bidang SDM dikumpulkan secara sistematis dalam apa yang di sebut manajemen sumber daya manusia. Istilah " manajemen mempunyai arti sebagai pengetahuan tentang bagaimana seharusnya mengelola sumber daya manusia.

Manajemen adalah suatu proses perencanaan, pengorganisasian, pengarahan dan pengawasan usaha-usaha anggota organisasi dan sumber daya manusia organisasi yang telah ditetapkan. Handoko (2010:3). Menurut Hasibuan (2007 : 1) Manajemen adalah ilmu dan seni mengatur proses pemanfaatan sumber daya manusia dan sumber-sumber lainnya secara efektif dan efisien untuk mencapai tujuan. Menurut Fathoni (2006 : 7) Manajemen dapat disebut pembinaan, pengendalian, pengelolaan, kepemimpinan, ketatalaksanaan yang merupakan proses kegairahan untuk mencapai tujuan yang telah ditentukan sebelumnya. Ketiga pengertian di atas dapat dipahami bahwa manajemen merupakan suatu proses perencanaan, pengarahan dan pengendalian dalam organisasi untuk mencapai tujuan yang ditetapkannya dengan mengelola sumber daya yang ada. Handoko (2010:4) Manajemen sumberdaya manusia adalah penarikan, seleksi, pengembangan, pemeliharaan, dan penggunaan sumberdaya manusia untuk mencapai baik tujuan-tujuan individu maupun organisasi. Simamora (2006:4) Manajemen sumberdaya manusia adalah pendayagunaan, pengembangan, penilaian, pemberian balas jasa, dan pengelolaan individu anggota organisasi atau kelompok karyawan. Manajemen sumberdaya manusia adalah proses pengendalian berdasarkan fungsi manajemen terhadap daya yang bersumber dari manusia. Fathoni (2006:10)

Menurut Simamora (2006:610) disiplin adalah prosedur yang mengoreksi atau menghukum bawahan karena melanggar peraturan atau prosedur. Disiplin merupakan bentuk pengendalian diri karyawan pelaksanaan yang teratur dan menunjukan tingkat kesungguhan tim kerja didalam sebuah organisasi. Menurut Hasibuan (2007:193) berpendapat bahwa kedisiplinan adalah kesadaran dan kesediaan seseorang menaati semua peraturan perusahaan dan norma-norma sosial yang berlaku. Kedisiplinan harus ditegakkan dalam suatu organisasi perusahaan. Tanpa dukungan disiplin karyawan yang baik, sulit bagi perusahaan untuk mewujudkan tujuannya. Jadi, kedisiplinan adalah kunci keberhasilan suatu perusahaan dalam mencapai tujuannya. Sedangkan menurut Lembaga Administrasi Negara (2008:278) disiplin kerja pegawai adalah alat yang digunakan untuk membangun komunikasi antara bawahan dengan atasan agar mereka bersedia untuk mengubah suatu perilaku serta sebagai suatu upaya untuk meningkatkan kesadaran dan kesediaan seseorang mentaati semua peraturan dan norma-norma sosial yang berlaku.

Lembaga Administrasi Negara (2008:271) Kinerja adalah pengukuran terhadap tingkat penyelesaian tugas-tugas yang dilakukan oleh pegawai selama masa tertentu dengan menggunakan instrumen yang sesuai dengan karakteristik tugas tersebut. Simamora (2006:409) kinerja merupakan tingkat karyawan mencapai persyaratan proses pekerjaan. Fahmi (2013:127) mengatakan kinerja adalah hasil yang diperoleh oleh suatu organisasi baik 
organisasi tersebut bersifat profit oriented dan non profet oriented yang dihasilkan selama satu periode waktu.

\section{METODE PENELITIAN}

Sumber datanya adalah pegawai di Biro Pemerintahan Setda Provinsi Jambi yang menjadi responden penelitian, kuisioner ini berbentuk pertanyaan tertutup dimana alternatif jawabannya telah tersedia dari 1-5 (menggunakan skala Likert format lima jawaban). Untuk memperoleh data dan informasi yang diperlukan maka pengumpulan data dan informasi tersebut dilakukan dengan cara sebagai berikut :

1. Penelitian Pustaka (Library Research), yaitu suatu penelitian kepustakaan dengan jalan mempelajari literatur dan hasil-hasil penelitian yang berkaitan dengan masalah yang diteliti.

2. Penelitian Lapangan ( Field Research), yaitu suatu penelitian yang dilakukan melalui tehnik obesrvasi dengan melakukan pengamatan langsung terhadap kegiatan pegawai di Biro Pemerintahan Setda Provinsi Jambi, serta melalukan wawancara kepada mereka untuk mendapatkan informasi.

Populasi adalah wilayah generalisasi yang terdiri atas obyek atau subyek yang mempunyai kuantitas dan karakteristik tertentu yang ditetapkan oleh peneliti untuk dipelajari dan kemudian ditarik kesimpulannya, sedangkan sampel adalah bagian dari jumlah dan karakteristik yang dimiliki oleh populasi tersebut. Sugiyono (2014:63). Populasi dari penelitian ini adalah seluruh pegawai di Biro Pemerintahan Setda Provinsi jambi tahun 2017 sebanyak 43 orang. Dengan menggunakan teknik random sampling semua pegawai yang berada di Biro Pemerintahan Setda Provinsi Jambi dipilih untuk menjadi sampel dalam penelitian ini.

Penelitian ini penulis akan menganalisis data yang diperoleh secara deskriptif kualitatif. Analisis dilakukan berdasarkan teori yang mempunyai kaitan erat dengan aspek yang diteliti. Menurut Syekh (2011:247) analisis deskriptif merupakan bentuk analisis data penelitian untuk menguji generalisasi hasil penelitian yang didasarkan atas satu sampel. Analisis deskriptif ini dilakukan melalui pengujian hipotesis deskriptif.

Untuk mencari rentang skala menurut Rangkuti (2001:58) digunakan rumus sebagai berikut :

$$
\text { Rentang Skala }=\frac{n(m-1)}{m}
$$

Dimana : $\mathrm{n}=$ jumlah sampel; $\mathrm{m}=$ jumlah alternatif jawaban item

Rentang Skala $=\frac{43(5-1)}{5}$

$\mathrm{Rs}=34,4$
Maka :

$\begin{array}{ll}43-77,4 & =\text { Sangat Tidak Baik } \\ 77,5-111,9 & =\text { Tidak Baik }\end{array}$

$112-146,4=$ Cukup Baik

$146,5-180,9=$ Baik

$181-215,4=$ Sangat Baik

Untuk menjawab tujuan penelitian tersebut digunakan analisis regresi linier sederhana. Menurut Saleh (2004:110) rumus persamaan regresi linier sederhana adalah sebagai berikut :

$Y=a+b X+E t$

Dimana : $\mathrm{Y}=$ kinerja; $\mathrm{a}=$ konstanta; $\mathrm{b}=$ koefisien regresi; $\mathrm{X}=$ disiplin; $\mathrm{Et}=$ error term (residual)

\section{Teknik Analisis Data \\ Koefisien Korelasi}

Menurut Kurniawan (2009:26) korelasi adalah hubungan atau keeratan antara 2 variabel, dimana terdiri dari 1 variabel independen (bebas) dan 1 variabel dependen (terikat) dan juga mengetahui arah hubungan. Adapun pedoman arti korelasi sebagai berikut :
$0,00-0,199$
$=$ Sangat tidak erat
$0,20-0,399$
$=$ Tidak erat
$0,40-0,599$
$=$ Cukup erat
$0,60-0,799$
$=$ Erat
$0,80-1,000$
$=$ Sangat erat

\section{Koefisien Determinasi}

Menurut Supardi (2013:188) koefisien determinasi dilambangkan dengan $r^{2}$. Nilai ini menyatakan proporsi variasi keseluruhan dalam nilai dependen yang dapat diterangkan atau diakibatkan oleh hubungan linear dengan variabel independen, selain itu (sisanya) diterangkan oleh variabel yang lain (galat atau peubah lainnya). Nilai koefisien determinasi dinyatakan dalam kuadrat dari nilai koefisien korelasi $\quad r^{2} \times 100 \%=n \%$, memiliki makna bahwa nilai variabel dependen dapat diterangkan oleh variabel independen sebesar $\mathrm{n}$ $\%$, sedangkan sisanya sebesar $(100-n) \%$ diterangkan oleh galat (error) atau pengaruh variabel yang lain. Sedangkan untuk analisis korelasi dengan jumlah variabel dependen lebih dari 1 (ganda / majemuk) terdapat koefisien determinasi penyesuaian (adjustment) yang sangat sensitif dengan jumlah variabel. Biasanya untuk analisis korelasi majemuk / ganda yang sering dipakai adalah koefisien determinasi penyesuaian (koefisien determinasi sederhana tidak memperhatikan jumlah variabel independen). Rumus yang dipakai adalah :

$\mathrm{KD}=\mathrm{r}^{2} \times 100 \%$

Keterangan : $\mathrm{KD}=$ Koefisien determinasi; $r=$ Koefisien korelasi

\section{Uji Statistik $t$}

Uji $t$ digunakan untuk menentukan apakah variabel bebas faktor disiplin kerja (X) 
berpengaruh secara simultan terhadap variabel terikat kinerja ( $\mathrm{Y}$ ). Rumus yang digunakan adalah :

1. Rumusan Hipotesis

$$
\begin{aligned}
& \mathrm{Ho}: \mathrm{b}-0 \\
& \mathrm{Hi}: \mathrm{b} \neq 0
\end{aligned}
$$

2. Tentukan tingkat signifikan dengan $\alpha=5 \%$

3. Perhitungan nilai $t$

$$
t_{\text {hitung }}=\frac{b}{S(b)}
$$

Dimana :

$\mathrm{t}=$ hasil $\mathrm{t}$ hitung

$S=$ standar eror dari variabel independent

$\mathrm{b}=$ koefisien regresi
4. Kritertia keputusan

Jika thitung $>$ tabel artinya Berarti Ho ditolak, tidak ada pengaruh signifikan (nyata) disiplin kerja terhadap kinerja

Jika thitung < trabel artinya Berati Ho diterima, ada pengaruh signifikan (nyata) faktor disiplin kerja terhadap kinerja.

\section{HASIL DAN PEMBAHASAN}

Hasil rekap jawaban responden secara keseluruhan berdasarkan urutan prioritas penilaian terhadap disiplin pada Biro Pemerintahan Setda Provinsi Jambi dapat dilihat pada tabel berikut ini :

Tabel 1

Rekap Jawaban Responden Terhadap Sub Indikator Disiplin Kerja

\begin{tabular}{llll}
\hline No. Urut & Sub Indikator & Skor & Keterangan \\
\hline 1 & Menaati semua bentuk aturan yang telah ditetapkan. & 178 & Baik \\
2 & Loyalitas terhadap tugas dan perintah yang telah diberikan oleh atasan. & 179 & Baik \\
3 & Semangat dan berantusias dalam menjalankan pekerjaan & 184 & Sangat Baik \\
4 & Memaksimalkan tenaga dan pikiran dalam menjalankan pekerjaan & 183 & Sangat Baik \\
5 & Tidak membuang waktu, tepat, dan cermat dalam menjalan pekerjaan & 193 & Sangat Baik \\
6 & Waktu dan pekerjaan yang diberikan sesuai yang diharapkan & 172 & Baik \\
7 & Melaksanakan semua perintah dan pekerjaan & 175 & Baik \\
8 & Tugas yang diberikan terlaksana dengan baik & 180 & Baik \\
9 & Siap menerima resiko terhadap pekerjaan yang dijalankan & 172 & Baik \\
10 & Ketepatan datang dan pulang kerja sesuai dengan jam yang telah ditentukan & 184 & Sangat Baik \\
11 & Absensi selalu baik dengan ditunjukan minimnya ketidakhadiran & 181 & Sangat Baik \\
12 & Tidak bolos pada saat jam kerja & 185 & Sangat Baik \\
Total & & $\mathbf{2 . 1 6 6}$ & Baik \\
Rata-rata & & $\mathbf{1 8 0 , 5}$ & \\
\hline Sumber: data olahan
\end{tabular}

Hasil jawaban responden berdasarkan urutan prioritas indikator kinerja pada Biro
Pemerintahan Setda Provinsi Jambi dapat dilihat sebagai berikut :

\begin{tabular}{|c|c|c|c|}
\hline No. Urut & Sub Indikator & Skor & Keterangan \\
\hline 1 & Pengembangan dimulai dari diri sendiri & $\overline{181}$ & Sangat Baik \\
\hline 2 & Efektif dalam menentukan pola pekerjaan & 175 & Baik \\
\hline 3 & Selalu memberikan inovasi dalam melakukan pekerjaan & 172 & Baik \\
\hline 4 & Saling mengisi dan mendukung rekan sesama & 181 & Sangat Baik \\
\hline 5 & Bekerja secara tim dapat mempermudah pekerjaan & 179 & Baik \\
\hline 6 & Selalu saling percaya terhadap rekan sesama & 172 & Baik \\
\hline 7 & Tepat waktu dalam menyelesaikan pekerjaan & 188 & Sangat Baik \\
\hline 8 & $\begin{array}{l}\text { Selalu terampil dan tidak mengeluh dalam melaksanakan pekerjaan yang telah } \\
\text { diberikan }\end{array}$ & 167 & Baik \\
\hline 9 & $\begin{array}{l}\text { Sebelum bekerja sebaiknya melakukan perencanaan agar hasil sempurna yang } \\
\text { didapatkan }\end{array}$ & 182 & Sangat Baik \\
\hline 10 & Kualitas kerja dapat selalu diandalkan & 171 & Baik \\
\hline 11 & Mempunyai keahlian untuk selalu dipertahankan dalam menjalankan pekerjaan & 177 & Baik \\
\hline 12 & Bersifat terbuka terhadap atasan, rekan, dan organisasi dalam pekerjaan & 170 & Baik \\
\hline 13 & Penyampaian kerja yang mudah dimengerti & 168 & Baik \\
\hline 14 & Memberikan penjelesan dengan baik dalam hal penyampaian kerja & 175 & Baik \\
\hline $\begin{array}{l}\text { Total } \\
\text { Rata-rata }\end{array}$ & & $\begin{array}{l}2.458 \\
175,58\end{array}$ & Baik \\
\hline
\end{tabular}

Tabel 2

Rekap Jawaban responden terhadap Sub Indikator Kinerja

Sumber : Data olahan

\section{Persamaan Regresi Linear Sederhana}

Untuk mengetahui pengaruh disiplin kerja terhadap kinerja pada Biro Pemerintahan Setda Provinsi Jambi dilakukan dengan metode analisis regresi linear sederhana, dimana pengaruh tersebut dapat dilihat dari nilai koefisien masing-masing variabel yang menggambarkan bentuk pengaruh variabel independent terhadap variabel dependent. Hasil perhitungan analisis linear sederhana dengan menggunakan software SPSS windows versi 23.0 dapat dilihat pada tabel dibawah ini 
Tabel 3

Hasil Perhitungan Regresi Linear Sederhana

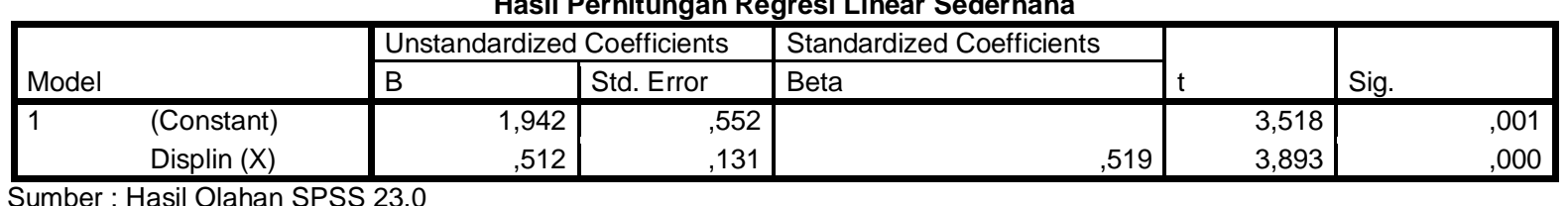

Berdasarkan tabel diatas, diperoleh persamaan regresi linear sederhana sebagai berikut :

$\mathrm{Y}=\mathrm{a}+\mathrm{bX}$

$Y=1,942+0,512 X$

Persamaan regresi diatas dapat disimpulkan bahwa nilai konstanta (a) adalah 1,942 artinya jika disiplin kerja bernilai 0 (nol), maka kinerja bernilai positif yaitu 1,942. Untuk nilai koefisien korelasi variabel disiplin kerja (b) bernilai positif juga yaitu 0,512 , ini dapat diartikan jika disiplin Kerja ditingkatkan 1\% maka kinerja ( $(Y)$ pada Biro Pemerintahan Setda Provinsi Jambi akan bertambah 0,512\%. Untuk melihat erat atau tidak hubungan antara variabel disiplin dan kinerja tersebut digunakan analisis korelasi, dari hasil perhitungan SPSS untuk melihat koefisien korelasi dapat dilihat pula pada model summary berikut ini :

Tabel 4

Hasil Perhitungan Koefisien

\begin{tabular}{|l|l|l|l|l|}
\hline Model & R & R Square & Adjusted R Square & Std. Error of the Estimate \\
\hline 1 &, $519^{\mathrm{a}}$ &, 270 &, 252 &, 22982 \\
\hline
\end{tabular}

Sumber : Hasil Olahan SPSS 23.0

Hasil tabel diatas, nilai koefisien korelasi (r) sebesar $0,519 \quad(51,9 \%)$ artinya terdapat hubungan yang cukup erat antara disiplin kerja dan kinerja pegawai pada Biro Pemerintahan Setda Provinsi Jambi. Sementara itu koefisien dtereminasi dipergunakan untuk melihat seberapa besar pengaruh disiplin terhadap kinerja pada Biro Pemerintahan Setda Provinsi Jambi, dari penelitian sebagaimana terlihat pada tabel model summary bahwa nilai koefisien determinasi $\left(R^{2}\right)$ sebesar 0,270 atau $27 \%$, artinya kinerja pegawai pada Biro Pemerintahan Setda Provinsi Jambi sebesar 27\% dipengaruhi oleh disiplin kerja, dan selebihnya $73 \%$ dipengaruhi oleh faktor lain yang tidak diteliti dalam penelitian ini.

\section{Uji Hipotesis t}

Untuk menguji hipotesisnya perlu diuji test statistik untuk b (koefisien arah regresi) dengan menggunakan langkah-langkah sebagai berikut :

1. $H_{0}: \mathrm{b}=0$ (tidak ada pengaruh disiplin kerja terhadap kinerja pegawai Biro Pemerintahan Setda Provinsi Jambi)

2. $H_{1}: \mathrm{b} \neq 0$ ( ada pengaruh disiplin kerja terhadap kinerja pegawai Biro Pemerintahan Setda Provinsi Jambi)

3. Pilih interval keyakinan $=95 \%$ berarti tingkat signifikan $5 \%$

4. Kriteria hipotesis :

t hitung $>\mathrm{t}$ tabel berati $H_{0}$ ditolak dan menerima $H_{1}$ $\mathrm{t}$ hitung $<\mathrm{t}$ tabel berarti $H_{0}$ diterima dan menolak $H_{1}$

Uji t yang dipergunakan untuk melihat apakah disiplin berpengaruh secara nyata atau tidak terhadap kinerja pegawai Biro Pemerintahan Setda Provinsi Jambi, uji $t$ dipergunakan dengan membandingkan nilai $t$ hitung terhadap tabel statisitik. Hasil perhitungan pada Tabel 3 diatas, diperoleh nilai $t$ hitung untuk variabel disiplin kerja $(X)$ sebesar 3,893. Dengan tingkat keyakinan $95 \%$ atau $a=5 \%$ untuk uji satu arah $\mathrm{df}=41$ (43-2) maka diperoleh $\mathrm{t}$ tabel sebesar 2,019. Hal ini berarti nilai t hitung lebih besar dari t tabel sehingga $H_{0}$ atau disiplin kerja tidak berpengaruh terhadap kinerja ditolak, dan $H_{1}$ atau disiplin kerja berpengaruh terhadap kinerja diterima. Artinya dengan diterima $H_{1}$ berarti secara parsial disiplin kerja memiliki pengaruh yang signifikan terhadap kinerja pegawai pada Biro Pemerintahan Setda Provinsi Jambi dengan tingkat signifikan sebesar 0,00.

\section{SIMPULAN}

Berdasarkan penelitian yang telah dilakukan, maka dapat ditarik kesimpulan mengenai hasil penelitian, yaitu sebgai berikut :

1. Secara keseluruhan penilaian disiplin pegawai pada Biro Pemerintahan Setda Provinsi Jambi masuk dalam kategori baik. Indikator terendah terdapat pada tanggung jawab dalam pekerjaan dan tugas dengan nilai rata-rata sebesar 175,7 dan indikator tertinggi terdapat pada tingkat absensi dengan nilai rata-rata 183,3 
2. Secara keseluruhan penilaian kinerja pegawai pada Biro Pemerintahan Setda Provinsi Jambi masuk dalam katergori baik. Indikator terendah terdapat pada pelayanan dengan nilai rata-rata sebesar 171 , dan indikator tertinggi terdapat pada keakuratan kerja.

3. Disiplin kerja dinyatakan berpengaruh secara positif dan signifikan terhadap kinerja pegawai Pada Biro Pemerintahan Setda Provinsi Jambi. Disiplin kerja mempengaruhi kinerja pegawai sebesar $27 \%$, dan $73 \%$ sisanya di pengaruhi oleh faktor-faktor lain.

\section{DAFTAR PUSTAKA}

A.A Anwar Prabu Mangkunegara 2011 Manajemen Sumber Daya Manusia Perusahaan PT Remaja Resdakarya Bandung

Handoko, T.Hani. Manjemen Sumber Daya Manusia, BPFE, Yogyakarta 2005

Hasibuan, Malayu. SP. Organisasi dan Motivasi Dasar Peningkatan Produktivitas, Bumi Aksara Jakarta 2003

Hasibuan, Malayu. SP. Manajemen Sumber Daya Manusia, Gunung Agung. Jakarta 2005

Istijanto, 2009 Aplikasi Praktis Riset Pemasaran, Jakarta : Gramedia Pustaka Utama

Masrukhin dan Waridin 2004, Pengaruh Motivasi Kerja, Kepuasan Kerja, Budaya Organisasi, Dan Kepemimpinan Terhadap Kinerja Pegawai. Ekobis Vol 7 No.2 Hal 197-209

Nitisemito, Alex. S 2000 Manajemen Personalia (Manajemen Sumber Daya Manusia), Edisi Ketiga, Jakarta : Ghalia Indonesia

Rivai Veitzhal 2011 Manajemen Sumber Daya Manusia Untuk Perusahaan PT. Raja Grafindo Persada Jakarta

Syadam, Gouzali, Manajemen SDM, Djambatan, 2005

Syaukani, Affan Gaffar dan Ryaas Rasyid, 2002. Pokok-pokok Organisasi dan Manajemen. Jakarta: Rieneke Cipta

Sukirno Sadono 2005. Mikro Ekonomi Teori Pengantar, edisi ketiga. PT Raja Grafibdo Persada : Jakarta 